University of Wollongong

Research Online

Faculty of Social Sciences - Papers (Archive) Faculty of Arts, Social Sciences \& Humanities

$1-1-2016$

Governing food choices: a critical analysis of school food pedagogies and young people's responses in contemporary times

Deana Leahy

Monash University, deana.leahy@monash.edu

Jan Wright

University of Wollongong, jwright@uow.edu.au

Follow this and additional works at: https://ro.uow.edu.au/sspapers

Part of the Education Commons, and the Social and Behavioral Sciences Commons

Research Online is the open access institutional repository for the University of Wollongong. For further information contact the UOW Library: research-pubs@uow.edu.au 


\title{
Governing food choices: a critical analysis of school food pedagogies and young people's responses in contemporary times
}

\author{
Abstract \\ Recently a proliferation and intensification of school programmes that are directed towards teaching \\ children and young people about food has been witnessed. Whilst there is much to learn about food, \\ anxieties concerning the obesity epidemic have dramatically shaped how schools address the topic. This \\ article draws on governmentality to consider 'the conditions of possibility' for teaching about food in \\ contemporary times. In particular the form that knowledge about food takes in the midst of an obesity \\ epidemic, the authorities on which it draws for its legitimacy and the learnings made possible are \\ considered. To do this two Australian studies investigating students' engagement with school-health \\ knowledge are considered. It is suggested that the obesity epidemic has potently shaped the ways \\ schools seek to teach about food and the possibilities for how young people come to understand their \\ own, and others', food choices.

\section{Keywords} \\ food, governing, analysis, contemporary, critical, choices, responses, people, young, pedagogies, school, \\ times

\section{Disciplines} \\ Education | Social and Behavioral Sciences

\section{Publication Details} \\ Leahy, D. \& Wright, J. (2016). Governing food choices: a critical analysis of school food pedagogies and \\ young people's responses in contemporary times. Cambridge Journal of Education, 46 (2), 233-246.
}


Leahy, D. \& Wright, J. (2016) Governing food choices: a critical analysis of school food pedagogies and young people's responses in contemporary times, Cambridge Journal of Education, 46(2), 233-246, doi: 10.1080/0305764X.2015.1118440.

\section{Introduction}

Food choice and provision have long been entangled in the everyday workings of schools. Such entanglements are evident in the work of $19^{\text {th }}$ century school health and temperance campaigners advocating sound nutritional practices and temperance (Gard \& Pluim, 2014); in the early school kitchen classrooms of the domestic sciences (Wessell, 2013); and more recently in a myriad of school food programs providing milk, fruit and breakfasts to children. Food has thus been a school policy staple and, while there has been sustained attention paid to food in schools over time, during the past decade we have witnessed a proliferation and intensification of school programs and initiatives targeting children and young people's food choices. The flurry of activity has been driven by contemporary anxieties related to the perceived threat of rising levels of the overweight and obese. It is also driven by the policy assumption that schools are ideal settings for obesity prevention and intervention (Gard \& Wright 2005; Rich 2010; Vander Schee \& Gard 2011). This article critically examines how such interventions in the form of food pedagogies operate to govern children's behaviour, but also points to how young people's responses to these messages demonstrate how such techniques have only a limited impact on young people's behaviours in the context of their values, pleasures and tastes associated with food.

The so-called 'crisis' of the obesity epidemic has had a profound effect on schools and the ways in which they are called upon to respond to the 'problem' of food and young people's food choices. In Australia for example, we have witnessed the introduction of school food policies attempting to regulate what kinds of foods students (and staff) can consume at school. School canteen policies provide guidelines about what kinds of foods can and cannot be sold at school. Other policies target school lunchboxes and prescribe what parents can and cannot pack in their child's lunchbox (Pike \& Leahy, 2012). In some cases the offending lunches have been sent home to parents if they contravene the accepted food wisdom of the day (O'Flynn, 2015). Such practices are not confined to Australia. For example, early in 2014, a six year old schoolboy was suspended from an English school because he had 'mini cheddars' in his 
lunchbox (Shaikh, 2014). School dinners and dining rooms in England and the US have also come in for significant attention from policy makers, as well as celebrity chefs (see Pike, 2015; Vander Schee \& Kline, 2013). In conjunction with, and perhaps because of, the flurry of policy changes, we have observed the emergence of a raft of other related practices that attempt to regulate food choice and consumption. For example, Pike and Leahy (2012) discuss the lunchtime practice of lunchbox surveillance, a practice they argue which is particularly designed to target and educate working class mothers who are discursively constituted as lacking the capacity to feed their children well. This practice involves teachers walking around the lunchroom while children are eating their lunches to inspect the nutritional contents of lunchboxes. Teachers can elect to make examples out of particular lunches by highlighting 'good' lunchboxes and shaming 'bad' ones. There are of course many different variations on this depending on the food setting. In the UK, dinner ladies, for example, patrol dining halls, casting their eyes over what children are eating and then allocating rewards for good manners or good food choices (Pike, 2008). Teachers have also found themselves the target of interventions because of the obesity epidemic. Vander Schee and Gard (2014) in their analysis of public health legislation, policy documents and academic literature describe how teachers are being called on to inspire 'health’ amongst their students. To do this they need to be 'role models' who embody a healthy weight and eat appropriate foods in front of their students. Additionally they discuss examples of school districts that run holiday weight competitions for teachers that seek to 'Maintain, don't gain' so that they return in the new year with the same weight.

In addition to the school food policy initiatives and practices that seek to regulate food consumption, there are a number of curriculum initiatives that require students to participate in targeted lessons about food, health and eating. In Australia, while these lessons might take place in a range of different subject areas, the topic of food tends to be taught in the curriculum area of health education in both primary and secondary schools. Food lessons in health education are usually explicitly designed around the imperative to cultivate personal decision-making capacities to ensure that students, when confronted with a food choice, make the right choice (Leahy \& Pike, 2015). This particular focus on healthy food decision-making is made explicit in the new Australian Curriculum: Health and Physical Education (ACARA, 2014, p. 5) where the first of the learning foci is 'making healthy choices in relation to food and nutrition', followed by 'understanding energy needs' - a code we suggest in the context of policy 
pressures around obesity, for managing weight. It is important to note though that the lessons not stop only attempt to regulate the quantity and kinds of food that students eat in an attempt to curb overweight and obesity, such lessons also attempt to shape young people's food desires, practices, values and taste. While such aspirations may not be explicitly stated in curriculum documents, they are ever present and function as part of the broader governmental project targeting food and morality in contemporary times (Coveney, 2006).

While it is possible to point to food related curriculum imperatives in official curriculum documents, there has been less research on how these particular imperatives manifest themselves within the classroom and how such attempts are received by young people themselves. This paper addresses this gap by first drawing on the notion of biopedagogies to examine specific examples of food pedagogies used in Australian classrooms. Second, we use interviews from students in primary and secondary schools to ask how the ideas about food that are promoted by these pedagogies impact the ways students might come to understand themselves, and others, in relation to food and health.

In order to engage with the layers of complexity involved in understanding school food pedagogies we divide the article into three sections. The first section provides a discussion of the field of governmentality studies and the related concept of biopedagogies as the theoretical terrain that informs our discussion. In this section we work on the premise that school food pedagogies operate as key governmental spaces for the enactment of broader health imperatives (Leahy \& Pike, 2015). Given this, we consider the implications this has for both the development and delivery of food pedagogies. In the second section we examine the various moves employed as pedagogical strategies to shape young people's food choices. In the third section we turn to consider how children and young people make sense of the kinds of health messages promoted by such food pedagogies. We conclude by suggesting that food pedagogies that are developed and the lessons learned in health education about food, its consumption and practices have implications for perpetuating some problematic understandings about the self and others.

In the second and third sections we draw on empirical data from two separate studies undertaken in five secondary schools in Victoria and three primary and three secondary schools in New South Wales, Australia (see Leahy 2012; Wright, Burrows \& 
Rich 2012 for more detail). While these studies are situated in different Australian states they complement each other and draw on data from similar contexts. Both states use very similar Health Education curricula. The Victorian study provides data collected from observations of health education lessons and interviews with teachers but did not involve interviews with students, while the New South Wales provides data collected through interviews with teachers and students and general field notes about the school health education environments, but did not involve classroom observations. Both studies involved a critical analysis of health education curriculum documents and teaching resources.

Although more detailed observational data were collected of classroom practice in the Victorian schools, informal observations in the NSW schools, together with the collection of documentation, suggests close parallels in the general approach to teaching about food. Food and physical activity/fitness were taught formally, often coupled with physical activity/fitness, in the broader context of 'healthy lifestyles' - that is, avoiding lifestyle diseases and particularly obesity. Because of the greater attention to classroom practice in the Victorian study, the section on food pedagogies will focus on data from this study. The section on how students make sense of food will draw on data from the NSW study. We acknowledge the limitations of drawing on data from two different studies but would argue that the NSW student data offer possibilities to demonstrate young people’s more general response to both school-based food pedagogies and food knowledge circulating more widely.

\section{Governing food choice in contemporary times}

In attempting to understand the emergence of the myriad of school food related policies, their accompanying food pedagogies, and in turn the imagined and real effects, it is useful to draw on governmentality studies, and the concept of biopedagogical assemblages (Leahy, 2009; Wright \& Harwood, 2009). Michel Foucault understands government as 'way in which the conduct of individuals or groups might be directed: the government of children, of souls, of communities, of families, of the sick ... to govern in this sense, is to structure the possible field of action' (Foucault, 1991, pp. 220-221). Government, for Foucault, refers not only to disciplinary power that shapes the range of possibilities open to individuals within a field of action, but also to the ways in which individuals are encouraged to act upon themselves to regulate their own 
conduct with particular ends in mind. Shaping the conduct of individuals then involves various programmatic attempts 'to foster and shape such capacities so that they are enacted in ways that are broadly consistent with particular objectives such as order, civility, health or enterprise' (Rose, 2000, p. 323). The development of various school food policies then can be understood to be directly about curtailing students' and teachers' food choices while they are at school by limiting food options. In conjunction with school food policy, school food (bio)pedagogies provide what Burchell (1996) refers to as essential and necessary 'contact points' for government where connections can be forged between the imperatives of government and the space of bodies, lives, selves and persons (Dean, 2010).

Food pedagogies, then, do not simply come into being. Rather they are developed with a specific purpose in mind. Ellsworth (2005) understands such purposes to be 'pedagogy's force' - a force that is both behind, and woven through, pedagogy. The forces shaping food pedagogies in contemporary times are largely fuelled by the 'urgent' need to curb the obesity epidemic by reducing risk factors associated with obesity. In conceptualising food pedagogies then we need to extend our analysis beyond simply contemplating the forces that sit behind the pedagogy, in other words the governmental imperatives, and consider the forces woven through pedagogy's enactments. To do this we draw on the concept of biopedagogical assemblages (Leahy 2009, 2012; Wright \& Harwood, 2009) to grapple with the multiple and complex discourses and techniques that are at play within curriculum, resources and classrooms. The analytic concept of biopedagogical assemblages is forged from analytical lines derived from Foucault's (1978) concept of biopower and from the broader field of governmentality studies (Dean, 1999; Rose, 2000). The term biopedagogies, according to Wright and Halse (2013), describes the values and practices that are disseminated through both formal and informal educational sites to instruct, regulate and construct understandings of citizens and their bodies. Effectively biopedagogies operate as what Miller and Rose (1990) refer to as technologies of governmentality. In contemplating governmentality, Dean (1999) and Rose (2000) draw our attention to the conceptual messiness and complexity that characterises any attempt to shape the conduct of the population. Dean for example suggests that practices of government and, for our purposes here, pedagogy cannot be conceived of as a coherent whole, and instead 'should be approached as composed of heterogeneous elements having diverse historical trajectories, as polymorphous in their internal and external relations, and as 
bearing upon a multiple and wide range of problems and issues’ (1999, p. 29). In adding to understandings of current practices of government, and thus pedagogy, Rose suggests that:

...current control [pedagogical] practices manifest, at most, a hesitant, incomplete, fragmentary, contradictory and contested metamorphosis, the abandonment of some old themes, the maintenance of others, the introduction of some new elements, a shift in the role and functioning of others because of their changed places and connections with the 'assemblage' of control (2000, p. 322).

Food pedagogies and their effects are not then as straightforward as policy and curriculum writers, textbooks or resources might have us believe. We also need to take into account what Probyn (2004) refers to as the 'hurly burly' of classrooms - where food pedagogies are enacted and where different actors, rationalities and technologies converge to create complex assemblages. By drawing attention to these levels of complexity we suggest that it is possible to better understand how food is both thought and taught about in classrooms, and received by the intended subjects.

\section{Schooling food}

As previously stated, food (bio)pedagogies are considered integral to preventing and/or reducing the incidence of overweight and obesity in children and young people. The rationale for lessons within this particular equation then, is about ensuring that students acquire certain nutritional knowledges and skills that will, in turn, enable them to make healthy food choices. This in and of itself is not unusual and has been a feature of health and physical education classrooms for sometime (Burrows \& Wright, 2007; Leahy \& Harrison, 2004). However what is of interest to the present discussion are the ways in which students are instructed and enticed to become healthy citizens. In particular, we are interested to consider the mechanisms by which this happens, as well as the kinds of understandings that these biopedagogical encounters produce in relation to food, health, pleasure, morality and citizenship.

Each of the schools in the Victorian study included formal lessons about food in their curriculum, under the guise of nutrition. In four of the schools, nutrition was also taught in conjunction with fitness. The focus of the units was on developing healthy 
lifestyles by improving your diet and your activity levels. The use of the term nutrition, and its coupling with physical fitness, is an interesting curriculum move in and of itself that prioritises and valorises particular perspectives and approaches to teaching and learning about food and the body. At the same time it displaces other potential approaches to engaging with the study of food.

In each school the length of time dedicated to the study of nutrition varied significantly. In one school, Year 10 students were required to study a 10 -week unit on nutrition and healthy lifestyles. In other schools, nutrition was covered in 3 x 50 minute lessons or in a four week sequence of 100 minute lessons. In another school, students learned about food in Home Economics across a 10-week term. The course included a focus on both cooking skills and learning about nutrition. Various strategies were utilised across the five schools to teach students about the benefits of eating well and conversely the perils of not eating well. Students were exposed to a variety of statistics about changing (and escalating) rates of overweight and obesity in children and young people. Teachers used textbooks, government websites and YouTube clips to make their points about food, health and the obesity crisis. Despite the variation in timetabled offerings, and curriculum locales, the lessons all emanated from the explicit desire to shape young people's food choices and practices. The lessons, too, all followed similar plot lines and featured similar pedagogical strategies. In the following discussion we focus on two popular food pedagogies: food diaries and decision-making. Both strategies are often combined together to enlist young people into what Dean (1995, p. 563) refers to as the process of 'governmental self formation'.

\section{Food diaries}

The pedagogical strategy of compiling a food diary (whether it be for a day or for a week) combined with dietary analysis was popular across all school sites. This combination of strategies provides students with an opportunity to develop insights into their diet, understandings about key nutrients and their function, as well as develop an understanding of their 'energy in'. In encouraging students to record their daily, or weekly, food intake and then analysing it, teachers drew from a range of resources to support student learning. For example teachers utilised online resources or textbooks to help students complete the recording of, and analysis of their daily or weekly diets. As a pedagogical sequence, food diaries and their analysis and comparison with standards or 
norms has significant government support in Victoria, via the state-wide distribution of a teaching resource called The Gobbiliser (Department of Education and Training, 2007). The Gobbiliser was developed for the explicit purpose of supporting students to conduct dietary analysis. It was one of a number of digital learning objects that were distributed to all Victorian schools on CDs as part of an initiative entitled Curriculum@Work. The Gobbiliser is a multi media digital resource that provides students with a colourful, fun and engaging interface. Students work their way through a number of screens that contain cartoon images to analyse their own, or someone else's diet. As students move through each screen they are asked to fill in or complete different tasks. Early on students are asked to enter details including their gender, age, name, physical activity, health status, food likes and dislikes, culture and religion and food preparation responsibilities. Once students have created their profile they are moved to the next screen where meal option tabs are presented to them alongside a giant mouth that is open and waiting to gobble down the components of each meal students select. Students work their way through the various meals, clicking through different options and selecting items that they have noted down in their food diaries. Students drag items across the open mouth and drop them in. Students can drag pictures of cups of coffee, eggs, hamburgers, rice etc. and place them in the mouth. Once students have worked their way through all of the meals and have placed all of their food intake into the mouth, they click on a button beneath the mouth that says 'swallow'. Once they press swallow, the mouth chews the food loudly a few times and then a swallowing noise is heard, followed by loud belching noise. As the belch booms out from the computer, students receive the Recommended Daily Intake (RDI) readout for their profile in the form of a graph that depicts the percentages consumed of each macronutrient and key vitamins and minerals. Students are also told their kilojoule intake for the day. At this stage students can elect to compare dietary needs for different aged people and people of different sexes. They are also provided with a button to the bottom right of the screen that says 'REGURGITATE'. If students select this button, they hear a loud vomiting sound and watch as the screen returns to the open mouth full of the food that had previously been swallowed. The Gobbiliser effectively provides students with insights into their daily food consumption via the display of the percentage of nutrients ingested and their energy intake. Such insights are instrumental for work on the self in ways that are consistent with health imperatives. Reducing food and the experience of eating simply to individualised scientific rationalistic input data is 
troubling enough, however what is more troubling in this pedagogical assemblage is the contradictory health message that regurgitating food is always a possibility. Within this one pedagogical assemblage, students learn about key nutritional knowledges, but they also encounter mixed messages about health. On one hand, they are engaging with a health imperative to eat well according to dietary guidelines; on the other, they encounter a provocation to purge their food should their intake have been inappropriate.

\section{Making healthy choices - decision-making}

Within health education assemblages, knowledge is often coupled with the life skills of decision-making and communication. This combination has been a mainstay of school health education for over thirty years (Leahy, 2012). Once students have acquired the relevant information, in this case nutritional knowledges, they then need to be able to translate their knowledge into action. To do this, contemporary curriculum and biopedagogical assemblages favour a focus on cultivating and refining individual decision-making skills. Decision-making is considered to be a pivotal skill that, according to policy and curriculum hopes, will ensure young people make healthy food choices.

In the study, approaches to teaching decision-making varied across schools. For example, teachers used worksheets, class brainstorms, and text books to encourage students to work through the decision-making process by listing possible options, contemplating the consequences of each option, and finally making an informed decision. More often than not, decision-making in the schools in the Victorian study was taught in conjunction with communication skills. This combination attempts to ensure students can communicate their decision effectively and persuade others to follow their example. The following classroom observation captures the pedagogical mix of learning about decision-making and communication in action. Prior to the lesson, students had studied what constitutes a good food choice. During this lesson the pie had been discussed at length and at the end of the discussion the teacher passed judgment on the pie proclaiming that it fell into the category of a 'bad food' choice. At the time there was some concern expressed by the students about judging the pie as not a good choice. One student, for example, asked about the status of a pumpkin and leek pie but did not receive an answer. 
The lesson that followed aimed to build on students' understandings of healthy (good) food choices, and was designed to help students develop the necessary life skills to make those healthy food choices. The teacher, using the example of the pie from the previous lesson, had designed the class so that students could both learn and practice the art of pie refusal skills. To do this, students were placed into pairs to do a role-play. The role-play functioned to provide a real life scenario where students could hone their life skills. It involved one student pretending to have a pie and their task was to convince their partner to take the pie. The idea being that the partner had an opportunity to practice 'just saying no' to pies. Once students had practiced their pie refusal skills, the teacher questioned each pair to find out who took the pie and who didn't. Those who indicated that they had indeed taken the pie were met with a look of shock and distaste and a disbelieving question of 'really, why?'

\section{Making sense of food}

The kinds of food pedagogies described above are typical of those used to teach nutrition in the context of health education curriculum across Australia. While the use of food diaries to teach about nutrients and energy values of food is common in secondary schools, the messages in primary schools are often much simpler, based on the food pyramid or more recently the 'food plate' or even more simply 'good foods', 'bad foods' and 'sometimes foods'. Resources from the Australian government '2 \& 5 Campaign' (2 vegetables and 5 fruit) are also popular and reflected in children's preference to nominate fruit and vegetable as healthy foods to the exclusion of all other foods (see below).

In the secondary schools in both studies the main focus in the first two years of high school was on 'healthy lifestyles' where students learned primarily about 'eating healthily', the benefits of physical activity, and balancing these so that you would remain healthy now and in the future. For most of the students interviewed in the NSW study health was understood in these simple terms - eating the right foods and engaging in enough physical activity. Many of the students interviewed described learning about this balance between foods and exercise in the context of avoiding overweight and obesity. It is clear that both primary and secondary students 'get the message' - bad foods are those high in sugar and fats - 'fast food', 'junk food', 'take away food' - and good foods seem primarily to be fruit and vegetables. The following two quotes from 
students are indicative of these narrow notions not only of what constitutes 'healthy' food but the very simple equation of good health with eating right and being physical active. As exemplified in the quotes below 'Eating the right food' or some more specific equivalent was the first response for most of the students to the question about their meaning of health.

Jane: It means lots of healthy things to eat, exercise, all different things that other people think would be good, like apples, bananas and fruit and vegetables.

Interviewer: So is there anything that is not healthy then?

Jane: Well, there is lots of junk food like chocolate and ice cream. Interviewer: What about you, Stacey, what does health mean to you? Stacey: Exercise, eat healthy fruit and do jogging and running and keep fit. (Female primary students)

A healthy body is eating the right thing and exercising half an hour a day at least. You don’t eat a lot of junk food or sugary drinks. (Male secondary student)

Beyond this understanding of healthy food as fruit and vegetables and unhealthy foods as 'junk food' (chocolate featured regularly in the students' responses) and fast/takeaway food (e.g. McDonald's), the students' understanding of nutrition seemed confused and limited. If their families' or their own desires do not conform to these narrow parameters they are left with few choices that they can feel are appropriate. In the following series of quotes for example, Aden talks about how he would like to enjoy healthy food such as salads but explains his failure to enjoy such foods in terms of his upbringing. His 'knowledge' about healthy foods, however, means that he evaluates what he, his family and others eat, and his family generally comes out poorly in this comparison. In the first quote, for example, his mother's decision to bring in cooked food from outside the home, leaves Aden anxious that he and his family are headed for a future of ill-health.

And on that note with my parents like my dad is not home all the time but my mum, like last night for instance she had some steaks in the microwave and all that and about half an hour later she came and said “I don’t feel like 
steaks go out and get something for us to eat”. And because they share my diet it's not like they are all eating salads and I'm the only one who is not, we are all eating unhealthy and it is sort of worrying sometimes because I know it's not good and if we keep going the same way something is going to happen eventually. (Male student secondary school)

In an interesting reversal it is his parents' food practices that come under critical moral scrutiny in Aden's account, reversing the more usual references to children's practices as those which need to be managed or improved (Curtis, James \& Ellis, 2010). At the same time Aden's comments do indicate the kinds of familial power relations documented elsewhere (Curtis et al, 2010), where adults in the family determine what food is available for children's consumption, ironically in this case food which Aden determines to be less healthy.

In the second quote below in response to a question about where he obtains information about health, Aden nominates his observations of the kinds of choices his friends make in relation to food. In contrast to their apparent liking for 'healthy' foods, he describes his own desires for 'unhealthy foods', which he attributes to an upbringing where tastiness and practicalities were more important and neither of his parents were interested in the health values of food.

Aden: Well one that comes to me quite quickly is friends because a lot of my friends have been brought up differently to me and they do eat healthily and stuff and when I see them do it I think maybe if I did that I might be as healthy as them. I want to but it is really hard for me.

Interviewer: Do you watch like do you pay attention to what your friends eat?

Aden: A lot of the time like they might have salad roll and I'll go yeah this is really good. But I'll sort of look at them and wonder how you could find that good because if I went and tried that I probably wouldn't find it that nice.

Interviewer: So does watching what your friends are eating make you feel better or worse?

Aden: I suppose it makes me feel a little bit worse because they are eating something healthy and I'll usually have something unhealthy and I sort of 
wish it was the other way round but I know that it’s not. (Male secondary student)

In this interview Aden also points to how families' decisions about food are influenced by the cost of food and cites the comparative expense of food such as steak bought at the supermarket, compared to 'a barbecue chicken bought at a takeaway shop that could feed a family of four', suggesting either personal experience of hardship or, more likely in his context, an understanding of the economies of food choices.

In another example, Jay's comments point again to how pleasure and taste play a substantial role in young people’s choices of food and resistance to health messages, which are at the same time understood as providing moral guidance about what they 'should' be eating. Jay only rates his health as five to six and half out of ten (a low score amongst most of his peers) because, despite his activity and avoidance of 'junk food', he isn't all that keen on a full range of vegetables. It thus becomes impossible for him to reach an ideal or even a norm of good health because of what he perceives to be his restricted preferences.

Jay: I reckon yeah five, six and a half I guess because really I do sport and I'm training three days a week and playing a game on Saturdays and tennis on Sundays. But maybe I'm not eating as much junk food but the problem is I just don't like eating vegetables as much.

Interviewer: So what would you need to do to be higher do you reckon? Jay: Maybe eat more vegetables I guess. The only vegetables I can eat are carrots and potatoes and stuff. But I can’t eat broccoli and cauliflower. (male secondary student)

The messages about food produced in the food pedagogies described above have clearly taken hold. All of the students, both primary and secondary, could recite these simplest of messages about 'healthy' and 'unhealthy' foods. For some, the messages concerning the risks associated with eating 'bad foods' also had considerable traction, inducing anxiety if they were unable to comply with the appropriate choices, either through family practices they had little control over or their own preferences. For others, however, these incitements to make the decision to eat only 'good foods' and avoid 'bad' ones were so unrelated to their own tastes and desires, and to the more complex 
availability of food both in relation to school and their families, that while they could recite the discourse, they could ignore it and act pragmatically. The singularity of the message, as indicated above by the teacher's response to the student inquiry about choosing (or not) a pumpkin and leek pie, allows considerable space for acting differently. The following quote exemplifies the ironic juxtaposition of the dominant discourse with the material practicalities and desires that motivate action. While Tim inserts himself easily into the appropriate cadences of the discourse (although his comment 'an apple a day' could already been seen as not taking it all very seriously), his friend Aden challenges his neat recitation by pointing out that Tim is about to head off to McDonalds for his lunch.

Tim: Being active and not just sitting there and eating your Mackers. Interviewer: So it's about not eating bad food, for example.

Tim: Yeah, you can have some I guess but eating healthily and getting out in the fresh air and having fun.

Interviewer: So what kind of things are incorporated and in eating healthy? Tim: An apple a day keeps the doctor away.

Interviewer: So fruit, vegetables, is that what you are talking about? Tim: Yeah.

Interviewer: Or is there something broader?

Tim: I don't know, yeah fruit and veg; it doesn’t matter if you have junk food but just not all the time.

Aden: I'll just add that he wants to go to Mackers in half an hour. (male secondary students)

In the examples cited in this paper, education about food takes place in the 'hurly burly' of the classroom, and while the messages about the relationship between food and obesity are recited by teachers and supported by messages in the popular media, reality TV shows, news reporting and so on (Rich, 2011), like Brembeck and Johansson (2010), we would argue that the materiality of students' lives means there are spaces for resisting the message and acting otherwise. The stridency and pervasiveness of such messages, in the media and in the teachers' interviews, about those who fail to avail themselves of the information available and make the 'right' choices, points to the extent of young people's resistance to food imperatives and the consequent frustration 
of adults - parents, teachers, health professionals and governments - with this failure to conform.

\section{Conclusion}

Vander Schee (2008) states that the 'obesity epidemic has manufactured a sociopolitical environment in which interventions are deemed necessary and ideologically innocent' (p. 407). As a result we have witnessed a flurry of school food policies and the transformation of how food is taught about in school classrooms. But as Vander Schee (2008) goes on to add, such practices are far from ideologically innocent. Rather as Lupton (1996) and Coveney (2006) argue, attempts to intervene in people’s lives and in this case, their food consumption, are inevitably shaped by broader social, political and economic forces. Food (bio)pedagogies that are fuelled by the obesity epidemic then, can never be benign, nor ideologically innocent. Instead we suggest that in contemporary times, they are saturated with moral meanings and judgements about acceptable citizens, bodies, foods and ways of eating (Lupton, 1996; Coveney, 2006, Pike and Kelly, 2014). The food pedagogies discussed in this paper are directed towards students in an attempt to 'shape the conduct, aspirations, needs, desires and capacities ...[so as] to enlist them in particular strategies and to seek definite goals' (Dean, 1999, p. 563). Given the forces at play and the ends sought, food biopedagogies necessarily strip away the aesthetic, social, political and cultural complexities and entanglements of food in people’s daily lives (see Coveney \& Bunton, 2003; Flowers \& Swan, 2015) so that they can do their governmental work: to individualise, rationalise and sanitise food and its consumption.

While there is much to say about the various food pedagogies detailed above we want to highlight the 'possibilities' open to students within these pedagogical moments. On first glance it appears that students are being encouraged to think about food and make decisions about what they are going to consume. But we want to suggest, that this is in fact a pedagogical illusion that characterises contemporary food biopedagogies and health education pedagogies more broadly (see Gard \& Leahy, 2009). In making this claim we follow Rose (1996), who understands free choice to be artificially arranged and contrived in contemporary times. In thinking about the biopedagogies detailed above then, decision-making and free choice is discursively foreclosed. For example, 
the idea that anyone would decide to eat a pie given what they [should] 'know' about pies, is deemed unthinkable by the teacher. In fact the expectation was that, given what students know about pies [pies are bad] all of the students should have 'just said no' to the pie. Within this moment students are subjected to an affective response from the teacher (of horror, of disbelief) that tells the students who accepted the pie that they made the wrong choice. Thus the food pedagogies in this study, that set out to cultivate decision-making skills, might be better understood to operate in reality as calls for obedience (see Gard, 2008).

A feature then of school food pedagogies, and their intended effects, is that they are never as straightforward as curriculum writers, resource developers and teachers might imagine. In attempts to prevent obesity for example, resources can inadvertently encourage other problematic practices, for example purging food. Other research too has highlighted the impossibilities and complexities produced by the need to 'prevent' obesity (Cliff \& Wright 2010; Gard \& Leahy, 2009). Despite the complexity and inconsistencies, the messages about food are being heard loud and clear by children and young people from sources both within and outside school. The problem though, as indicated by the discussion of food pedagogies and the students' responses, is that the messages are singular and emerge from scientific and instrumentalist approaches to understanding and engaging with the topic of food. The aesthetic, material, social, political and cultural complexities are removed and within this biopedagogical mix, other ways of thinking about food, bodies and lives are subjugated, ironically leaving students in the end with very limited resources to make decisions about food. Perhaps students would be better served if classrooms sought to engage with the complexities of food, its supply and availability, ethics, cultural meanings and aesthetics. In the Australian context, this would require an interdisciplinary approach to teaching about food in schools and a commitment to a socio-critical approach to health, the body and obesity in teacher education and professional learning (Leahy et al, 2016)

\section{References}

Australian Curriculum Assessment and Reporting Authority (ACARA). (2014b). Australian curriculum Health and Physical Education: Foundation to Year 10 Curriculum. Retrieved from: http://www.australiancurriculum.edu.au/healthand-physical-education/Curriculum/F-10?layout= 
Brembeck, H., \& Johansson, B. (2010). Foodscapes and children’s bodies. Culture Unbound, 2, 797-818.

Burchell, G. (1996). Liberal government and techniques of the self. In A. Barry, T. Osborne \& N. Rose (Eds.), Foucault and political reason (pp. 19-37). Chicago, IL: University of Chicago Press.

Burrows, L., \& Wright, J. (2007). Prescribing practices: Shaping healthy children in schools. International Journal of Children's Rights, 15, 1-16.

Cliff, K., \& Wright, J. (2010). Confusing and contradictory: Considering obesity discourse and eating disorders as they shape body pedagogies in HPE. Sport, Education and Society, 15, 221-233

Coveney, J. (2006). Food, morals and meaning: The pleasure and anxiety of eating. New York, NY: Routledge.

Coveney, J., \& Bunton, R. (2003). In pursuit of the study of pleasure: Implications for health research and practice. Health: An interdisciplinary journal for the study of health, illness and medicine, 7 (2), 167-179.

Curtis, P., James, A., \& Ellis, K. (2010). Children’s snacking, children’s food: Food moralities and family life. Children's Geographies, 8 (3), 291-302.

Dean, M. (2010). Governmentality: Power and rule in modern society (2nd ed.). London, England: Sage.

Dean, M. (1999). Governmentality. London, England: Sage.

Dean, M. (1995). Governing the unemployed self in an active society. Economy and Society, 24, 559-583.

Ellsworth, E. (2005). Places of learning: Media, architecture, pedagogy. New York, NY: Routledge.

Flowers, R., \& Swan, E. (2015). Food pedagogies: Histories, definitions and moralities. In R. Flowers \& E. Swan (Eds.), Food pedagogies (pp. 1-28). Surrey, England: Ashgate.

Foucault, M. (1991). Governmentality. In G. Burchell, C. Gordon \& P. Miller (Eds.), The Foucault effect: Studies in governmentality (pp. 87-104). London, England: Harvester Wheatsheaf.

Foucault, M. (1978). History of Sexuality, Volume 1: An introduction. New York: Random House.

Gard, M. (2008). Producing little decision makers and goal setters in the age of the obesity crisis. Quest, 60, 488-502. 
Gard, M., \& Leahy, D. (2009). Dicing with death: Tensions, contradictions and awkward positions in school health education. In M. Dinan Thompson (Ed.), Health and physical education: Contemporary issues for Australia and New Zealand. Oxford: Oxford University Press.

Gard, M., \& Pluim, C. (2014). Schools and public health: Past, present, future. New York, NY: Lexington Books.

Gard, M., \& Wright, J. (2005). The obesity epidemic: Science, morality and ideology. New York, NY: Routledge.

Leahy, D., Burrows, L., McCuaig, L., Wright, J., and Penney, D. (2016). School health education in changing times: Curriculum, pedagogies and partnerships. New York: Routledge.

Leahy, D. (2014). Assembling a health[y] subject: Risky and shameful pedagogies in health education. Critical Public Health, 24(2), 171-181.

Leahy, D. (2012). Assembling a health [y] subject. Unpublished dissertation. Deakin University.

Leahy, D. (2009). Disgusting pedagogies. In J. Wright \& V. Harwood (Eds.), Biopolitics and the obesity epidemic: Governing bodies (pp. 172-182). New York, NY: Routledge.

Leahy, D., \& Harrison, L. (2004). Health and physical education and the production of the 'at risk self'. In J. Evans, B. Davies \& J. Wright (Eds.), Body knowledge and control (pp. 130-140). London, England: Routledge.

Leahy, D., \& Pike, J. (2015). Just say no to pies: Food pedagogies, health education and governmentality. In R. Flowers \& E. Swan (Eds.), Food pedagogies. Surrey, England: Ashgate.

Lupton, D. (1996). Food, the body and the self. London, England: Sage.

Miller, P., \& Rose, N. (1990). Governing economic life. Economy and Society, 19, 131.

O’Flynn, G. (2015). Food, obesity discourses and the subjugation of environmental knowledge. Australian Journal of Environmental Education, 31 (1), 99-109.

Pike, J. (2015). Young people and food: The moral project of the healthy self. In P. Kelly \& A. Kamp (Eds.), A critical youth studies for the $21^{\text {st }}$ century (pp. 87104). The Netherlands: Kloninklijke Brill. 
Pike, J., \& Kelly, P. (2014). The moral geographies of children, young people and food. Beyond Jamie’s school dinners. Hampshire, England: Palgrave Macmillan.

Pike, J. (2008). Foucault, space and primary school dining rooms. Children’s Geographies, 6, 413-422.

Pike, J., \& Leahy, D. (2012). School food and the pedagogies of parenting. Australian Journal of Adult Education, 52, 434-460.

Probyn, E. (2004). Teaching bodies: Affects in the classroom. Body and Society, 10, 2143.

Rich, E. (2011). 'I see her being obesed': Public pedagogy, reality media and the obesity crisis. Health: An interdisciplinary journal for the study of health, illness and medicine, 15 (1), 3-21.

Rich, E. (2010). Obesity assemblages and surveillance in schools. International Journal of Qualitative Studies in Education, 23, 803-821.

Rose, N. (2000). Government and control. British Journal of Criminology, 40, 321-339.

Rose, N. (1999). Powers of freedom: Reframing political thought. Cambridge, England: Cambridge University Press.

Rose, N. (1996). Governing “advanced” liberal democracies. In A. Barry, T. Osborne \& N. Rose (Eds.), Foucault and political reason (pp. 37-64). Chicago, IL: The University of Chicago Press.

Shaikh, T. (2014, February 4). Six year old schoolboy suspended for having mini cheddars in his lunchbox has now been expelled. The Independent. Retrieved from http://www.independent.co.uk/news/uk/home-news/sixyearold-schoolboysuspended-for-having-mini-cheddars-in-his-lunchbox-has-now-been-expelled9109722.html

Vander Schee, C. (2008). Confessions of the 'unhealthy' - eating chocolate in the halls and smoking behind the bus garage: Teachers as health missionaries. British Journal of the Sociology of Education, 30, 407-419.

Vander Schee, C., \& Gard. M. (2014) Healthy, happy and ready to teach, or why kids can't learn from fat teachers: The discursive politics of school reform and teacher health Critical Public Health, 24(2), 210-225 doi 10.1080/09581596.2013.828152

Vander Schee, C., \& Gard, M. (2011). Editorial: Politics, pedagogy and practice in school health policy. Policy Futures in Education, 9, 307-314. 
Vander Schee, C., \& Kline, K. (2013). Neoliberal exploitation in reality television: Youth health and the spectacle of celebrity concern. Journal of Youth Studies, 16, 565-578. doi: 10.1080/13676261.2012.733812

Victoria Department of Education and Training. (2007).Curriculum@work. Retrieved from http://nla.gov.au/nla.arc-67767

Wessell, A. (2013). Cookbooks for making history: As sources for historians and as records of the past. M/C Journal, 16, Retrieved from http://journal.mediaculture.org.au/index.php/mcjournal/article/view/717

Wright, J., \& Halse. C. (2013). The healthy child citizen: Biopedagogies and weightbased health promotion. British Journal of Sociology of Education. 35(6) 836855 doi: 10.1080/01425692.2013.800446

Wright, J., \& Harwood, V. (2009). Biopolitics and the obesity epidemic: Governing bodies. New York, NY: Routledge.

Wright, J., Burrows, L. \& Rich, E. (2012) Health imperatives in primary schools across three countries: intersections of class, culture and subjectivity, Discourse, 33(5), 673-691. 